\title{
LEPTOPSYLLINES FROM MADAGASCAR \\ (INSECTA: SiPHONAPTERA: CERATOPHYLLIDAE): DESCRIPTION OF FIVE NEW SPECIES of Paractenopsyllus Wagner, 1938
}

\author{
DUCHEMIN J.B.*
}

\begin{abstract}
Summary :
Five new species of the malagasy endemic genus Paractenopsyllus Wagner, 1938, are described. Paractenopsyllus rouxi,

$P$. ratovonjatoi, $P$. duplantieri, $P$. juliamarinus and $P$. gemelli have been collected on endemic small mammals and the black rat. Biotopes are mid-elevation rain-forests of the central highlands or the northern mountains of Madagascar. Morphological affinities between these new species and those already known provide taxonomic links within the genus. Differences in the spatial and altitudinal distributions and host ranges allow discussion of the potential factors important in the species distribution of this genus.
\end{abstract}

KEY WORDS : Leptopsyllinae, Paractenopsyllus, new species, Madagascar

\section{INTRODUCTION}

D uring four years of field collections we have examined large series of Leptopsylline fleas (Hopkins \& Rothschild, 1971) and compared them with species already described by Wagner, 1938; Lumaret, 1962; Klein, 1965a \& b; Klein \& Grenier, 1965; Klein, 1967; Klein \& Grenier, 1969. Species of the genus Paractenopsyllus Wagner, 1938 : P. kerguisteli Wagner, 1938, P. pauliani Lumaret, 1962, P. grandidieri Klein, 1965, P. petiti Klein, 1965, P. viettei Klein, 1965, P. vauceli Klein, 1965, P. randrianasoloi Klein, 1968 and P. albignaci Klein, 1968, were compared with specimens kept in the "Institut pour la Recherche et le Développement" (IRD, ex-ORSTOM) Montpellier, France. We present here the description of five additional species. We then discuss the respective place of these species among the other members of the genus.

Deposition of types

Holotypes and allotypes deposited in the IRD Center of Montpellier, France where the most important col-

\footnotetext{
* Unité d'entomologie médicale, Institut Pasteur de Madagascar, BP 1274, Antananarivo 101, Madagascar.

Present address: Cermes, BP 10887, Niamey, Niger.

Tel.: 00227752045 - Fax : 00227753180 .

Email: duchemin@cermes.ne
}

Résumé : LePTOPSYLLINAE de MADAGASCAR (INSECTA: SiPHONAPTERA CERATOPHYLLIDAE): DESCRIPTION DE CINQ NOUVELLES ESPËCES DE PARACTENOPSYLLUS WAGNER, 1938

Cinq nouvelles espèces de Paractenopsyllus Wagner, 1938 genre endémique de Madagascar, sont décrites. Paractenopsyllus rouxi, $P$. ratovonjatoi, $P$. duplantieri, $P$. juliamarinus et $P$. gemelli ont été collectées à partir de micromammifères endémiques de Madagascar (excepté un rat noir). Leurs biotopes se situent au sein des forêts d'altitude moyenne, au niveau des hautes terres centrales ou des massifs septentrionaux. Les affinités morphologiques entre ces nouvelles espèces ainsi que celles déjà décrites permettent des rapprochements taxonomiques. Les différences de répartition et les spectres d'hôtes variés font discuter les facteurs éventuels de l'importante radiation spécifique de ce genre.

MOTS CLÉS : Leptopsyllinae, Paractenopsyllus, espèces nouvelles, Madagascar.

lection of types of this genus are kept. Paratypes deposited in the Field Museum of Natural History, Chicago, USA where many of the hosts collected during the campaign were deposited. Other paratypes in the Pasteur Institute of Madagascar, in the Pr J.-C. Beaucournu (Université Rennes, France) and author's collection.

Description of implicit attributes

Unless indicated otherwise, the following attributes are implicit throughout the full descriptions.

Head: frontal tubercle situated a little below the middle of the frons in the male and lower in the female. Submarginal row of frons is composed of 9-10 bristles. Six long bristles in the male and four in the female above the mouthparts. Genal ctenidium composed of two spines, the upper markedly longer than the lower. One stout bristle inserted behind the clypeus above the insertion of maxillary palps. The genal process apically dilated in the two sexes, the apex more broad and rounded in females. Eye relatively large and sinuate on its inferior and internal margins. Occipital chaetotaxy composed of four occipital rows of bristles including a sub-marginal posterior row; one unique bristle at the postero-inferior angle of the occiput. Labial palps extending to the middle of the coxa or a little beyond.

Thorax: prothorax with two rows of bristles. The length of the spines of the pronotal comb is shorter than the 
width of the prothorax. Mesothorax with five, rarely four rows of bristles and with two dorsal and one ventral pseudosetae. Metathorax with $4-5$ rows of bristles, the anterior row sometimes composed of only one fine bristle. As on the mesothorax, length of bristles increasing backwards. On the posterior margin 0-2 marginal spinelets (one per side). Metepimeron with three rows of bristles. False tibial combs present.

Abdomen (unmodified segments): first segments with three rows, the principal and posterior composed of nine bristles, one marginal spinelet on each side. On the others segments: 2-3 rows without bristles beneath the stigmata on $7^{\text {th }}$ segment in females. Three antesensilial bristles (ratio further given by sexe and starting from the most dorsal). Sternite II with one bristle on each side. Tergite VIII of male with three long bristles. Precise chaetotaxies of occipital, thoracic and abdominal unmodified segments will be further described. Sizes were measured on slide-mounted specimens.

\section{RESULTS}

\section{PARACTENOPSYLLUS ROUXI N. SP. (Figs 1-8)}

- Material examined

Holotype male, on the endemic rodent Eliurus majori Thomas, 1895 (FMNH 167635), Madagascar, Fianarantsoa, Ambalavao, Sandrisoa forest $\left(47^{\circ} 02^{\prime} \mathrm{E}, 22^{\circ}\right.$ 10' S), 1,600 m, Dec. 1999, Lala Andrianaivolambo and S.M. Goodman leg. Allotype female on the same host. Paratypes: on E. majori: one female, Madagascar, Fianarantsoa, Ambalavao, Andringitra National Park ( $46^{\circ}$ $\left.58^{\prime} \mathrm{E}, 22^{\circ} 11^{\prime} \mathrm{S}\right), 1,625 \mathrm{~m}$, Dec. 1993, B. O'Connor and S.M. Goodman leg. On the endemic rodent Eliurus tanala Major 1896: two males, three females, Andringitra National Park ( $46^{\circ} 58^{\prime} \mathrm{E}, 22^{\circ} 13^{\prime} \mathrm{S}$ ), 1,210m, Dec. 1993, B. O'Connor and S.M. Goodman leg.; one male, Sandrisoa forest ( $\left.46^{\circ} 01^{\prime} \mathrm{E}, 22^{\circ} 08^{\prime} \mathrm{S}\right), 1,300$ and $1,600 \mathrm{~m}$, Dec. 1999, Lala Andrianaivolambo and S.M. Goodman leg. On the endemic striped and spiny tenrec Hemicentetes nigriceps Günther, 1875: three males, Antananarivo, Ambositra, Ankazomivady forest ( $47^{\circ} 10^{\prime} \mathrm{E}, 20^{\circ}$ 45 ' S), 1,670 m, Jan. 1998, J.-B. Duchemin, J.-M. Duplantier and S.M. Goodman leg. On the black rat Rattus rattus (Linnaeus, 1758): two females, same site as immediately above.

- Hosts and distribution

All of the endemic rodent hosts recorded for P. rouxi belong to the genus Eliurus Milne-Edwards, 1885. The main species are E. majori and E. tanala. Other hosts are endemic hedgehog tenrecs of the sub-family Tenrecinae: H. nigriceps and Setifer setosus (Schreber, 1777 ). Black rats $R$. rattus are obviously secondary hosts. All sites of collection are situated south of the latitude $20^{\circ} \mathrm{S}$ and correspond to the southern part of the central highlands. Elevations range from 1,200 m to $1,670 \mathrm{~m}$; the lower elevations are the more southern.

- Etymology

This species is named for J.-F. Roux, Director of the Pasteur Institute of Madagascar during the recent field studies of plague in the Malagasy forests.

\section{- Diagnosis}

This species is close to P. grandidieri and P. randrianasolo $i$ with which it shares the large size and a pronotal comb with numerous spines. As well, $7^{\text {th }}$ sternite of the female bears only one lobe on it posterior margin. However this lobe reaches the inferior margin of the sternite and beyond with a massive rounded apex in $P$. rouxi n. sp. The male is separable by the shape of the dorsal lobe of the phallosome and the hamulus.

\section{- Description}

Head (Figs 1-2): no bristle of the frontal row thickened, the lower submarginal bristle often thin, or minute. The genal process with a concave superior margin. Occipital chaetotaxy as shown in Figures 1 and 2. Thorax: the pronotal comb composed of 31 to 35 spines in the males, and 33 to 36 in females.

Abdomen (unmodified segments): antesensilial bristles ratio of male: $0,4 / 1 / 0,3$ and female: $0,4 / 1 / 0,9$.

Modified male segments: tergite VIII with a straight or rarely convex upper margin with an apical angle of about $50^{\circ}$ and curved dorsad. Sternite VIII (Fig. 3) with a slightly concave superior margin. The apical margin sinuate with a convex, rounded dorsocaudal angle bearing five (4-6) long bristles, with the uppermost thiner and a lightly concave lower half bearing 2-3 long bristles near the caudoventral angle. Laterally 3-4 long bristles aligned obliquely forward and downward and sometimes one thiner anterior bristle. Nine to 15 bristles near the inferior margin on the posterior half of the sternite. Clasper (Fig. 4): basimere with a wellmarked acetabulum and the upper portion of the posterior margin slightly concave. Telomere long, moderately curved, the upper third widened with a rounded apex at the level or slightly beyond the apex of basimere. Setation well developed only on the upper third of the posterior margin. Sternite IX (Fig. 5): trapezoidal apical dilatation of proximal arm with a convexity on the upper margin of horizontal portion. Distal third dilated apically with a convex posterior margin bearing a patch of about 20 bristles extending to the lateral surface, with a few hairs on the anterior margin. The apex is extended cephalad by a neck and a basically rounded vertical distal lobe with a sharpened apex. Phallosome (Fig. 6): apex of dorsal lobe regular and rounded, extended by a ventral lobe laterally and by 

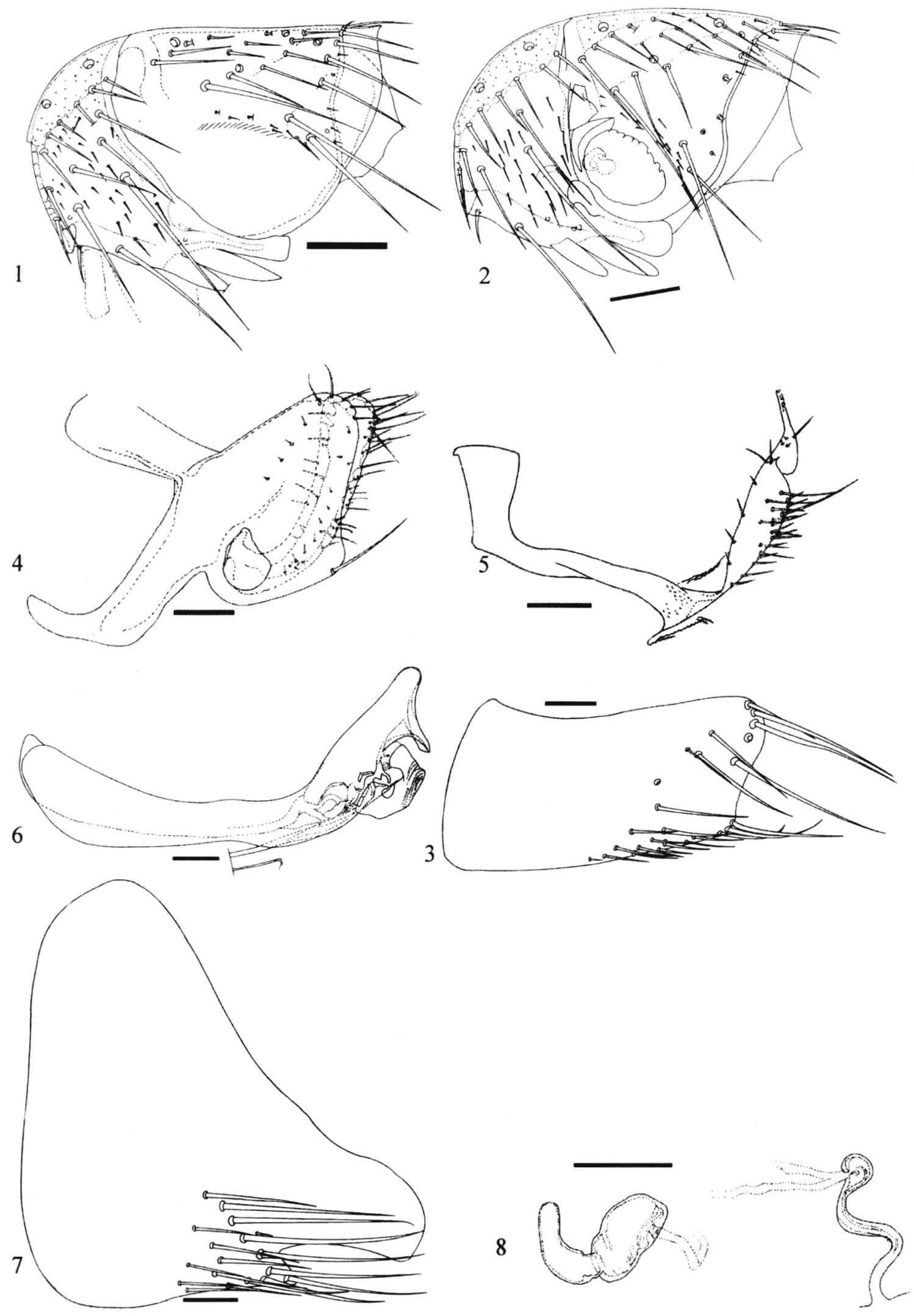

Figs 1-8. - Paractenopsyllus rouxi n. sp.

1: head of male; 2: head of female; 3: sternite VIII of male; 4: clasper of male; 5 : sternite IX of male; 6: phallosome; 7: sternite VII of female; 8: spermatheca and ductus bursae.

All scale bars $=0,1 \mathrm{~mm}$. 
two lobes wrapping the apex of hamulus. Hamulus robust with a strong distal arm that is vertically striped, its apex curved forward beneath the ventral lobe of phallosome. Endotendons extending cephalad beyond the tip of the broad lamina media.

Modified female segments: sternite VII (Fig. 7) with a lobe on the posterior margin, its apex large and rounded, extending caudoventrally beyond the inferior margin of the sternite. Its inferior margin with a concavity directed downward. It has a principal row of 5-7 strong submarginal setae with 9-14 anterior thiner bristles. Anal stylet variable (ratio L/1 2.1-3.7). Spermatheca (Fig. 8): bulga elongated (ratio L/ $1=1.75$ ), its superior margin convex, its inferior margin slightly straight, especially near the duct. Hilla shorter than the bulga (ratio H/B = 0.8). Ductus bursae S-shaped. Perula rounded, markedly sclerotized in it dorsal half.

Size: male $3.1-3.5 \mathrm{~mm}$, female $3.5-3.9 \mathrm{~mm}$.

PARACTENOPSYLLUS RATOVONJATOI N. SP. (Figs 9-16)

- Material examined

Holotype male, on the shrew-tenrec Microgale taiva Major, 1896 (FMNH 172596), Antsiranana, Andapa, Marojejy National Park ( $49^{\circ} 37^{\prime}$ E, $14^{\circ} 26^{\prime}$ S), 1,175 m , Oct. 2001, J. Ratovonjato and S.M. Goodman leg. Allotype female on the same animal.

Paratypes: on Microgale gymnorhyncha Jenkins, Goodman \& Raxworthy, 1996: one male, same locality and date and from Microgale talazaci Major, 1896: one female, same locality and date.

- Hosts and distribution

All the hosts recorded for $P$. ratovonjatoi are shrewtenrecs of the genus Microgale Thomas, 1882. The main species are $M$. taiva, M. talazaci, M. cowani Thomas, 1882, M. dobsoni Thomas, 1884 and more rarely $M$. gymnorbyncha and $M$. fotsifotsy Jenkins, Raxworthy \& Nussbaum, 1997. The second collection site is situated a few kilometres south of the type collection site $\left(49^{\circ} 25^{\prime} \mathrm{E}, 14^{\circ} 31^{\prime} \mathrm{S}\right)$ in a forest at elevations ranging from 1,250 to $1,450 \mathrm{~m}$.

\section{- Etymology}

This species is named for Dr. Jocelyn Ratovonjato, medical entomologist from the Pasteur Institute of Madagascar.

\section{- Diagnosis}

This species is unique in the genus Paractenopsyllus but may be placed close to $P$. petiti due to the numerous spiniform frontal bristles. Immediately separable from it by the male parameres and the shape of female sternite VII.

- Description

Head (Figs 9-10): about five frontal bristles near the frontal tubercle are markeclly spiniform, the others thickened. The upper spine of genal ctenidium moderately curved upward, especially on the inferior margin. Occipital chaetotaxy as shown in drawings.

Thorax: the pronotal comb composed of 23 to 25 spines, the ventral teeth longer than the dorsal ones, almost reaching the width of the inferior part of prothorax. No marginal spinelets on the posterior margin of metathorax.

Abdomen (unmodified segments): one spinelet on each side on the $2^{\text {nd }}$ to $5^{\text {th }}$ segments in males and from the $2^{\text {nd }}$ to the $4^{\text {th }}$ in females. Antesensilial bristles ratio male: $0,35 / 1 / 0,5$ and female: $0,3 / 1 / 0,9$.

Modified male segments: tergite VIII with a short and convex upper margin and a large rounded apical angle. Sternite VIII (Fig. 11) subquadrangular with a notch on the caudoventral angle. Two long thin bristles at the upper angle with two stronger long bristles laterally. Two long strong bristles on the ventral angle with 8-10 shorter bristles near the notch in the caudoventral margin.

Clasper (Fig. 12): basimere immediately separable from that of other Paractenopsyllus by the sclerotized recurvated postero-dorsal angle, opposing the apex of the telomere and forming two sides of a strong pincer. Posterior border of the basimere markedly convex at the level of the acetabulum with a single thin acetabular bristle. The vertical portion of the manubrium bears a notch on the third superior portion of the anterior border. Telomere robust and straight, the anterodorsal angle curved cephalad, sclerotized and beak-shaped. A fine vertical row of small bristles on the external face. Sternite IX (Fig. 13): distal third with a regular row of nine marginal bristles on the straight cephalic border. A large patch of about twenty fine bristles on the upper two-thirds of the posterior border and the lateral surface. The apex narrow with a distal lobe situated inside both the vertical part of sternite IX and the hamulus. This distal lobe is laterally flattened and fanshaped caudally. Phallosome (Fig. 14): characterized by a large and triangular dorsal lobe ending in a narrow, rounded apex. Hamulus with a neck closely articulated with the distal lobe of the sternite IX, smooth in its posterior part with a convex anterior margin. Endotendons extending beyond the tip of the broad lamina media with a $180^{\circ}$ angle.

Modified female segments: sternite VII (Fig. 15): apical border with two notches and two lobes. The upper lobe broad and rounded, the lower triangular and sharp (angle of apex about $30-45^{\circ}$ ) separated by a broad, open notch, the lower notch shorter and rounded with a superior border weakly deflected downwards. The apex of the lower lobe projecting beyond the ventroapical angle of the sternite VII. It has a principal row of five strong submarginal bristles extending beyond the posterior margin and about ten thiner bristles forwards. Anal stylet elongate (ratio 

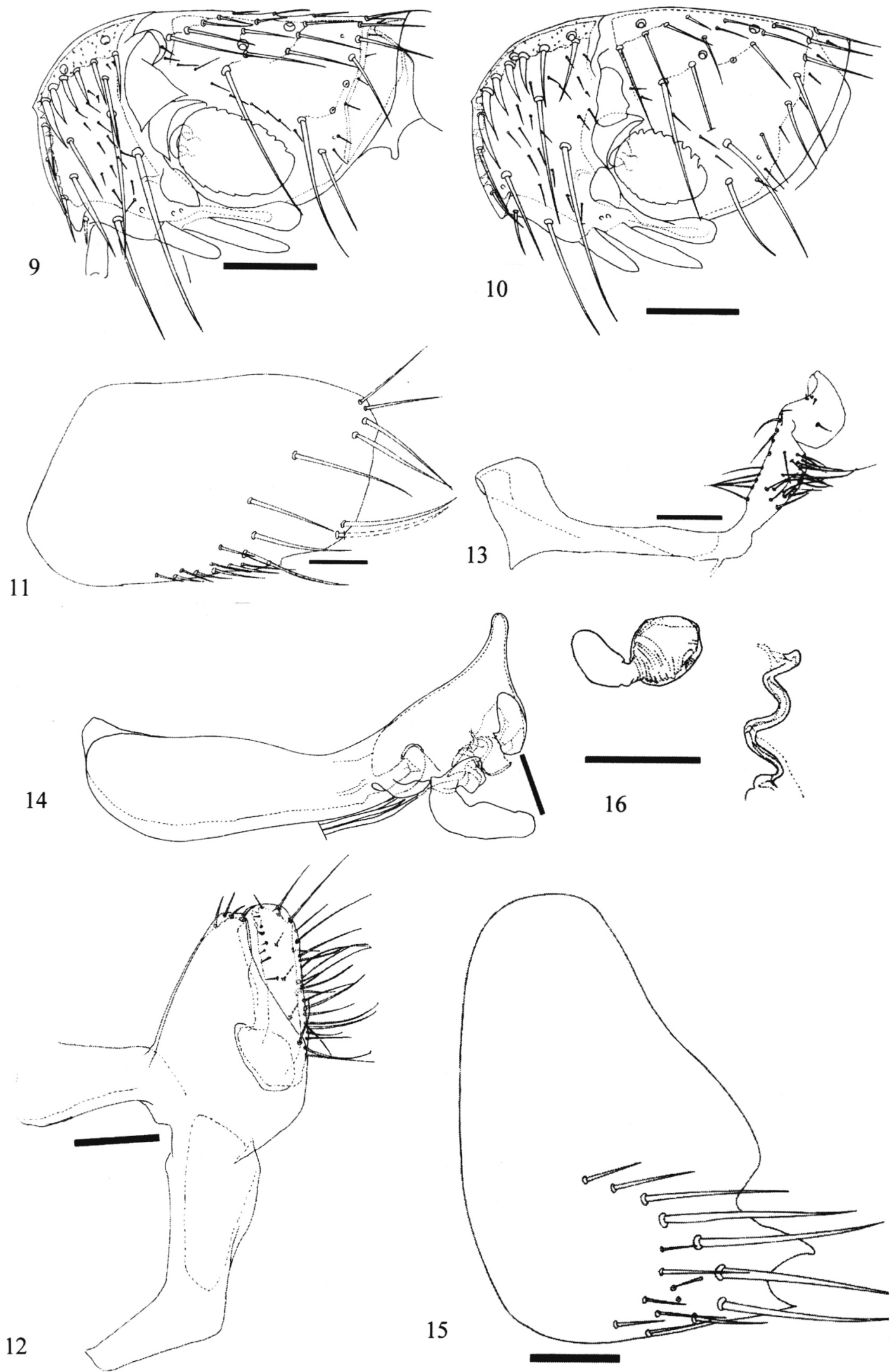

Figs 9-16. - Paractenopsyllus ratovonjatoi $\mathrm{n} . \mathrm{sp}$.

9: head of male; 10: head of female; 11: sternite VIII of male; 12: clasper of male; 13: sternite IX of male; 14: phallosome; 15: sternite VII of female; 16: spermatheca and ductus bursae.

All scale bars $=0,1 \mathrm{~mm}$. 
$\mathrm{L} / 1 \geqslant 3$ ), the ventral bristle inserted between the two halves. Spermatheca (Fig. 16): bulga sub-spherical (ratio $\mathrm{L} / 1=1.2$ ), hilla little arched and about as long as the bulga. Ductus bursae with almost four curves, perula very narrow and poorly sclerotized.

Size: male $2.6-2.7 \mathrm{~mm}$, female $2.5-2.7 \mathrm{~mm}$.

PARACTENOPSYLLUS DUPLANTIERI N. SP. (Figs 17-24)

- Material examined

Holotype male, on the shrew-tenrec Microgale taiva (FMNH 166176), Antananarivo, Ambatolampy, Ankazomena forest ( $47^{\circ} 50^{\prime} \mathrm{E}, 19^{\circ} 42^{\prime} \mathrm{S}$ ), 1,400 m , Jan. 1999, J.-M. Duplantier, J.-B. Duchemin and S.M. Goodman leg. Allotype female on a shrew-tenrec Microgale longicaudata Thomas, 1882 (SMG 10555) caught at the same date and locality.

Paratypes: on the same host as holotype: one male, same locality. On the same host as allotype: two males, same locality. On a shrew-tenrec $M$. cowani: one female, same locality. On a shrew-tenrec $M$. taiva : one female, same locality.

- Hosts and distribution

All the hosts recorded for $P$. duplantieri are from shrew-tenrecs of the subfamily Oryzorictinae. The main species are Microgale taiva, M. cowani, M. longicaudata, M. dobsoni Thomas, 1884 and more rarely M. thomasi Major, 1896, M. drouhardi G. Grandidier, 1934, M. fotsifotsy Jenkins et al., 1997, M. soricoides Jenkins, 1993 and the mole-like tenrec Oryzorictes hova A. Grandidier, 1870. A second site of collection is situated at a lower elevation $(1,100 \mathrm{~m})$ in the Vinanitelo forest Fianarantsoa, Vohitrapeno, Ambodivohitra (4729' E, $21^{\circ}$ 46' S).

\section{- Etymology}

This species is named for J.-M. Duplantier, mammalogist from IRD.

\section{- Diagnosis}

This species is unique in the genus Paractenopsyllus because of the shape of the basimere of the clasper and by the sternite VIII of the male. Its small size and poorly developed abdominal setation could be helpful for recognition in the two sexes.

- Description

Head (Figs 17-18): submarginal row of frons is composed of eight bristles of which the nearest to the frontal tubercle is often thickened. Five long bristles above the mouthparts in the female. The two spines of the genal comb are very close together and often slightly crossed in the males. Occipital setation as shown. Genal process with a convex superior margin. Thorax: the pronotal comb is composed of 24 or 25 spines. Antesensilial bristles length ratio of male: $0,35 / 1 / 0,4$ and female: $0,3 / 1 / 0,9$.
Modified male segments: tergite VIII with a straight dorsal margin and an apical angle mostly less than $90^{\circ}$. Sternite VIII (Fig. 19) with a sinuate dorsal margin. The narrow caudal apex bearing 6-7 long bristles with a thiner bristle on the upper angle. Laterally 0-2 long bristles and 1-2 long bristles near the inferior margin with 1-5 thiner anterior bristles. Clasper (Fig. 20): basimere immediately separable from that of other Paractenopsyllus by the relative length of the manubrium and the angle between the horizontal and vertical branches. Telomere very short and curved with a rounded apex. Sternite IX (Fig. 21): the proximal arm with a large quadrangular proximal dilation with a posterior and upper rounded angle and an apical beak-shaped projection. Distal third easily separable with a large lobe on the posterior margin bearing about 20 bristles, of which the two upper are markedly longer and curved upwards. The apex is extended interiorly by a constriction and a very dilated distal lobe which bears three minute hairs on its posterior angle on the internal surface. Phallosome (Fig. 22): apex of dorsal lobe large and rounded, extended by a ventral and posterior lobe with a square apex. Hamulus with the distal arm dilated with its caudoapical angle rounded and curved forming a globe-shaped lobe like a backwards-looking bird. Endotendons extending beyond the tip of the broad lamina media.

Modified female segments: sternite VII (Fig. 23): apical border with two lobes. The upper lobe broad, asymmetrical and rounded, the lower shorter and rounded (angle of apex about $30-45^{\circ}$ ) separated by a triangular (near or below $45^{\circ}$ ) notch; no real notch below the inferior lobe, it apex extending beyond the right angle of the inferior margin of the sternite VII. With a principal row of 2-3 strong submarginal bristles extending beyond the posterior margin subtending by two thiner bristles. Anal stylet variable (ratio L/1 2.5-3.5). Spermatheca (Fig. 24): bulga sub-spherical (ratio L/1 = 1.25), hilla slightly longer than bulga and broad (ratio $\mathrm{L} / \mathrm{l}=2$ ). Ductus bursae divided into two portions by a sclerotized angle, the inferior one with a single concave backward curve, the upper one as a question mark and more sclerotized than the proximal portion. Perula oval, elongated and poorly sclerotized.

Size: male 1.8-2.0 mm, female 2.1-2.4 mm.

PARACTENOPSYLLUS JULIAMARINUS N. SP. (Figs 25-32)

- Material examined

Holotype male, on a shrew-tenrec Microgale cowani (nº SMG 10916), Madagascar, Antsiranana, Antanambao, Manongarivo, ( $\left.48^{\circ} 25^{\prime} \mathrm{E}, 14^{\circ} 01^{\prime} \mathrm{S}\right), 1,600 \mathrm{~m}$, Mar. 1999, S.M. Goodman leg. Allotype female on the same animal.

Paratypes: on the same host as the holotype: one female. On a shrew-tenrec $M$. longicaudata: one male, 
17
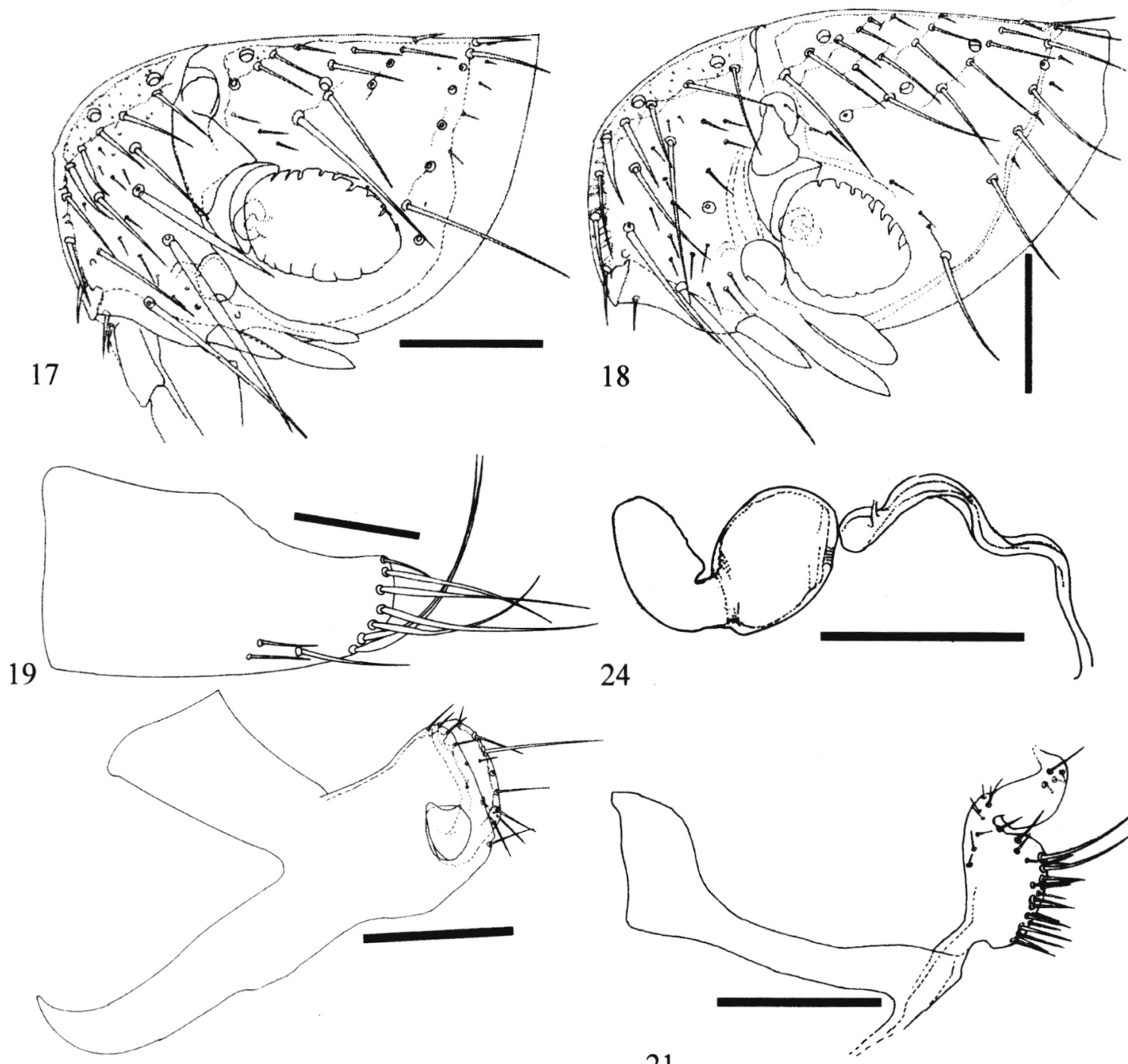

20

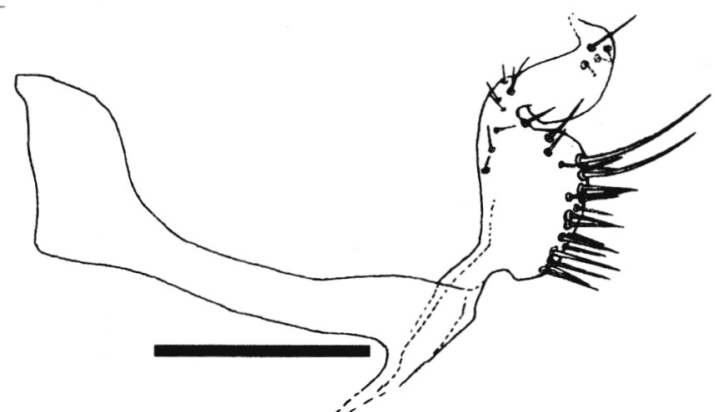

21

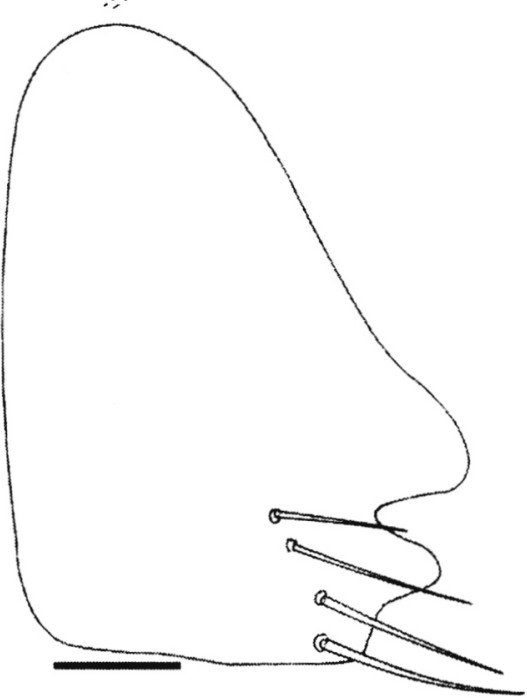

22

23

Figs 17-24. - Paractenopsyllus duplantieri n. sp.

17: head of male; 18: head of female; 19: sternite VIII of male; 20: clasper of male; 21: sternite IX of male; 22: phallosome; 23: sternite VII of female; 24: spermatheca and ductus bursae.

All scale bars $=0,1 \mathrm{~mm}$. 

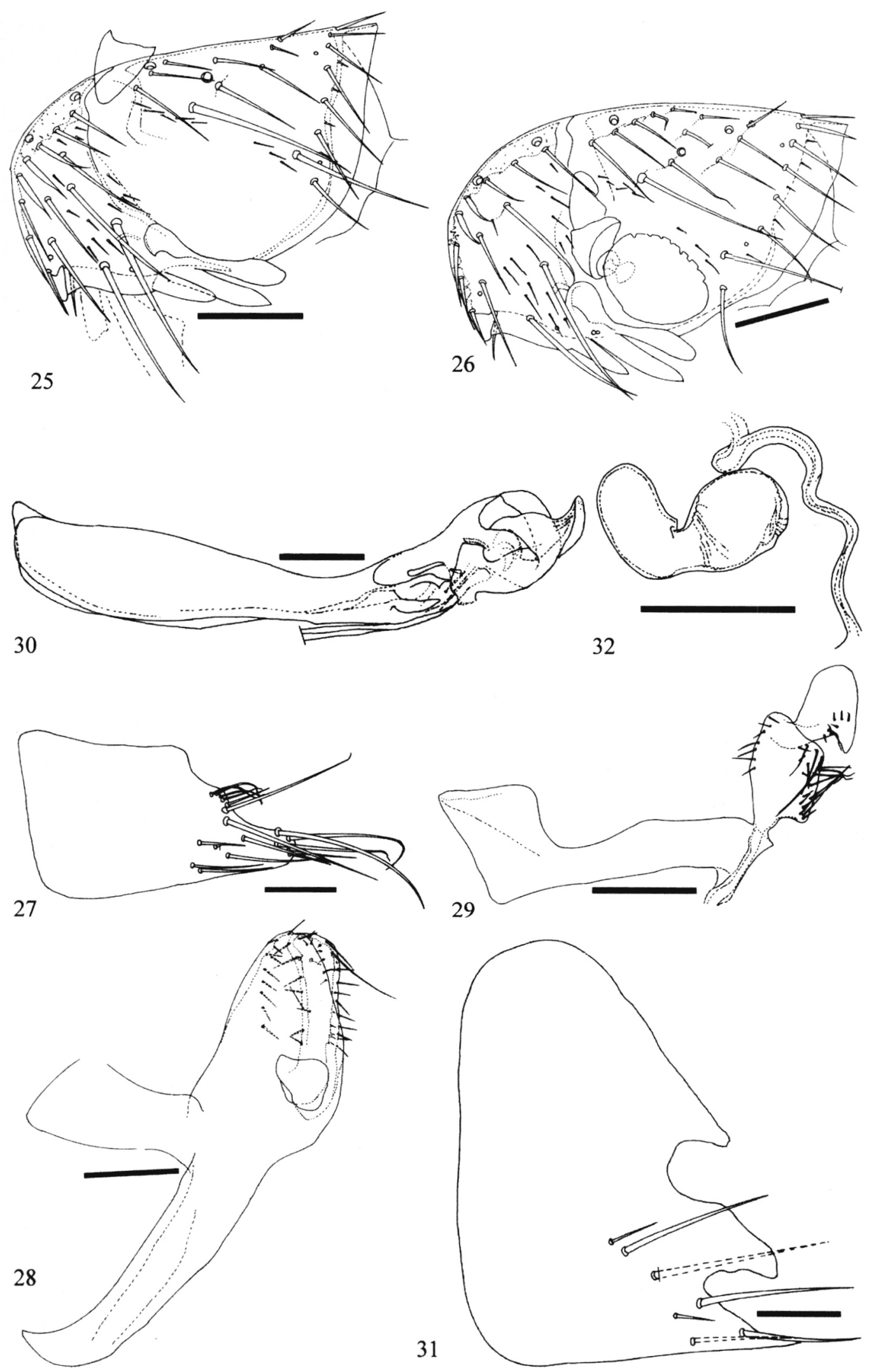

Figs 25-32. - Paractenopsyllus juliamarinus n. sp.

25: head of male; 26: head of female; 27: sternite VIII of male; 28: clasper of male; 29: sternite IX of male; 30: phallosome; 31: sternite VII of female; 32: spermatheca and ductus bursae.

All scale bars $=0,1 \mathrm{~mm}$. 
same locality. On a shrew-tenrec $M$. dobsoni: one female, same locality.

- Hosts and distribution

All the hosts recorded for P. juliamarinus are endemic shrew-tenrecs of sub-family Oryzorictinae belonging to three species: $M$. cowani, M. longicaudata and $M$. dobsoni. One unique specimen has been caught on an endemic rodent Eliurus grandidieri Carleton \& Goodman, 1998. All three collection sites are between 1,200 and $1,600 \mathrm{~m}$ and are situated in the northern highlands: Betaolana $\left(49^{\circ} 25^{\prime} \mathrm{E}, 14^{\circ} 36^{\prime} \mathrm{S}\right)$, Anjanaharibe-Sud $\left(49^{\circ} 25 \mathrm{E}, 14^{\circ} 45^{\prime} \mathrm{S}\right)$ and Manongarivo ( $48^{\circ} 25^{\prime} \mathrm{E}, 14^{\circ}$ 01'S).

\section{- Etymology}

This species is named for my two first children Julia and Marin who supported their father's interest in fleas.

\section{- Diagnosis}

This species shares many characteristics with $P$. duplantieri: for example, small size, poor setation and five bristles behind the frontal row in the female. However it can be clearly differentiated by genital characters and undoubtedly constitute a different species.

\section{- Description}

Head (Figs 25-26): submarginal row of frons composed of eight bristles of which the one nearest the frontal tubercle is often thickened. Five long bristles in the female above the mouthparts. The two spines of genal comb are very close and often slightly crossed in males. The genal process with a convex dorsal margin. Occipital chaetotaxy as shown in drawings.

Thorax: pronotal comb composed of 24 or 25 spines. Antesensilial bristles ratio of male: $0,3 / 1 / 0,4$ and female: $0,26 / 1 / 0,9$.

Modified male segments: tergite VIII with a straight upper margin and an acute apical angle of about $50^{\circ}$. Sternite VIII (Fig. 27) with a short, straight dorsal margin. The caudal margin has a rounded upper angle and two lobes: one median, slightly convex and bearing about 3-5 thin bristles and one long, strong bristle, and one lower lobe. The lower angle, strongly is convex, extends backwards and bears 4-5 long, flexible bristles. Laterally the sternite VIII bears 2-3 long bristles between the two lobes and 4-7 shorter ones cephalad. Clasper (Fig. 28): basimere immediately separable from that of other species by the long manubrium with an extremely tapered apex. The fixed process is relatively long with a rounded apex and the acetabular bristle is short and inserted at about the half of the height of this process. Telomere is slightly curved with a dilated apex. Sternite IX (Fig. 29): the proximal arm shows a quadrangular and massive apical dilatation. The distal arm carries a large lobe with a straight posterior margin bearing about 15 bristles, of which the upper two are markedly longer. The apex is extended interiorly by a constriction and a dilated distal lobe with an upper convex margin and a concave lower margin. Phallosome (Fig. 30): apex of dorsal lobe large and rounded, bearing a dorsal lobe that is weakly sclerotized. Hamulus with a dilated distal arm and a sharp apex. Modified female segments: sternite VII (Fig. 31). Apical border with two elongated lobes with deflected apecies. The upper concavity is roughly quadrangular and the lower one triangular, with an internal angle of about $45^{\circ}$. It has a principal row of five strong submarginal bristles which the upper is markedly thiner and two bristles forwards. Anal stylet variable (ratio L/1 2.1-3.2). Spermatheca (Fig. 32): bulga sub-spherical (ratio $\mathrm{L} / \mathrm{l}=1.25$ ), hilla a little bit longer than the bulga and very broad (ratio $\mathrm{L} / \mathrm{l}=2$ ). Ductus bursae drawing four curves without sclerotized angle. Perula oval, elongated and poorly sclerotized, the junction with the ducti spermathecae directed upwards.

Size: male 2.1-2.4 mm, female $2.2-2.7 \mathrm{~mm}$

\section{PARACTENOPSYLLUS GEMELLI N. SP. (Figs 33-40)}

- Material examined

Holotype male, on Eliurus myoxinus Milne-Edwards, 1885 (FMNH 172606), Madagascar, Antsiranana, Andapa, Marojejy National Park, Bemanavy forest ( $49^{\circ} 36^{\prime}$ E, $14^{\circ}$ 26 ' S), 810 m, Oct. 2001, S.M. Goodman and J.-B. Duchemin leg. Allotype female on the same animal. Paratypes: on the same host as holotype and allotype: three males, one female. On E. myoxinus: four males, four females, same collection site.

- Hosts and distribution

All hosts recorded for P. gemelli belong to the Eliurus genus. The higher flea index was recorded on E. myoxinus. Others specimens were taken on E. grandidieri, E. tanala and E. webbi Ellerman, 1949. The site of collection is situated in the northern mountains of Madagascar at a very narrow range of elevation. Only one specimen has been taken from other than the type-site at $400 \mathrm{~m}$ higher.

- Etymology

This species is named for my two twin children.

\section{- Diagnosis}

Although the mean size of this species is a bit smaller, this species is close to P. randrianasoloi Klein, 1968 sharing a hook-shaped dorsal lobe of the phallosome and one unique lobe of the sternite VII of the female. This lobe is smaller than P. randrianasoloi. The bulga of the spermatheca is regular with parallel sides while $P$. randrianasolo $i$ has an ovoid bulga with a posterior apex. The perula of $P$. gemelli is more vertically oval than the rounded one of $P$. randrianasoloi. The shape 

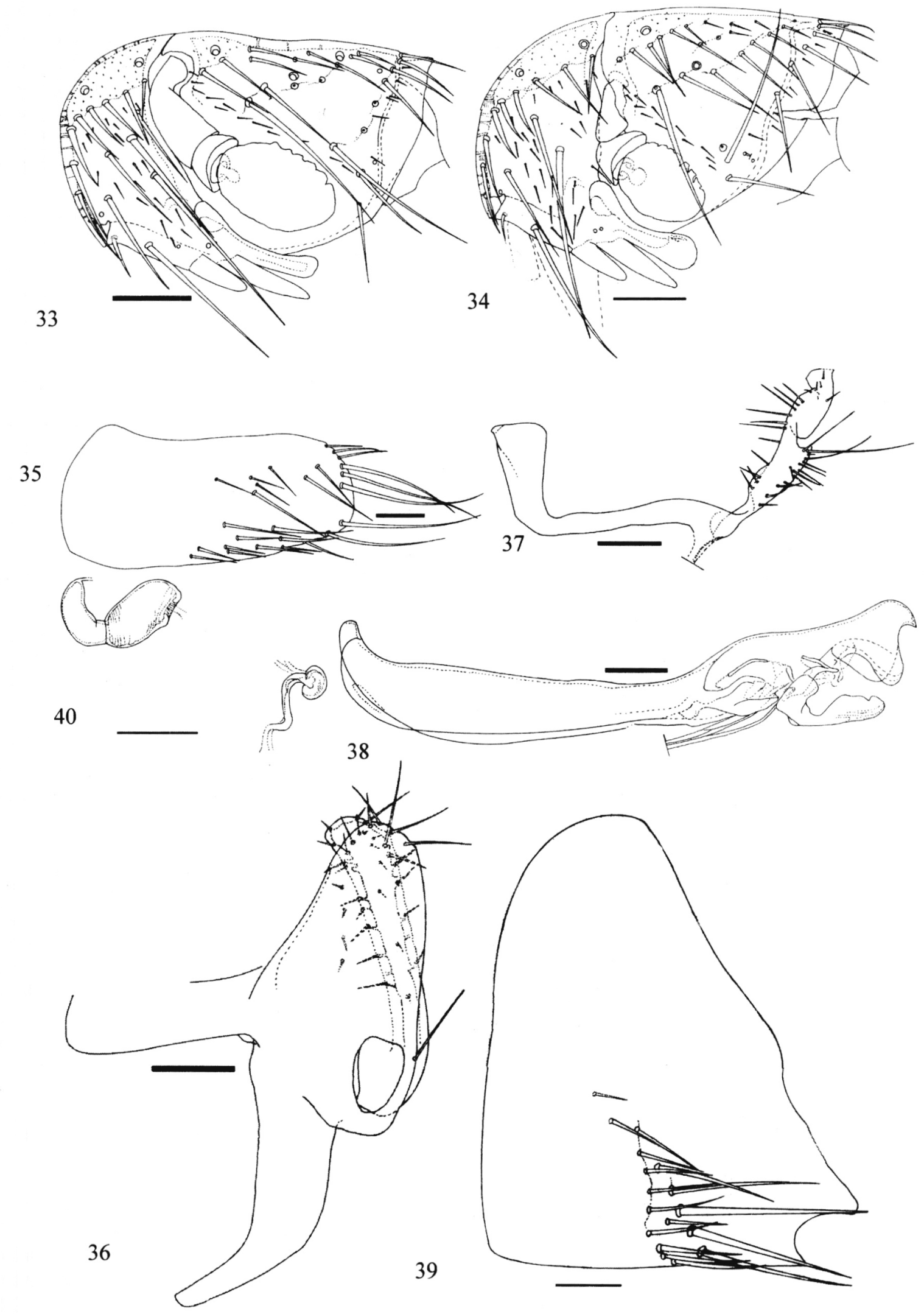

Figs 33-40. - Paractenopsyllus gemelli n. sp.

33: head of male; 34: head of female; 35: sternite VIII of male; 36: clasper of male; 37: sternite IX of male; 38: phallosome; 39: sternite VII of female; 40: spermatheca and ductus bursae.

All scale bars $=0,1 \mathrm{~mm}$. 
of the apex of the phallosome and the straighter apical border of the sternite VIII of $P$. gemelli complete differences with male $P$. randrianasoloi.

\section{- Description}

Head (Figs 33-34). The 2-5 sub-marginal frontal bristles near the tubercle are modified. Six, exceptionally seven, long bristles in the male above the mouthparts. Exceptionally one thiner spine above the two usual spines in the genal comb. The genal process is apically rounded in both sexes and bears a concave dorsal margin. Occipital chaetotaxy as in drawings.

Thorax: pronotal comb composed of 31 or 32 spines in the males and 33 or 34 in females. Antesensilial bristles ratio of male: $0,3 / 1 / 0,4$, female: $0,4 / 1 / 0,9$, the lower bristles being slightly but constantly bigger than the superior one in both sexes.

Modified male segments: tergite VIII with a convex, rarely straight, upper margin with an apical angle about $90^{\circ}$, rarely blunted and rounded. Sternite VIII (Fig. 35) with a straight or moderately concave dorsal margin. The apical margin curved with the lower and upper angles markedly rounded. Three strong long bristles along the upper half of the posterior margin beneath 2-3 thiner bristles on the upper angle. An elongated patch of about a dozen long bristles along the ventral margin of sternite VIII terminated by 2-3 (exceptionally one) on the caudoventral angle. Laterally an oblique row of 3-4 (exceptionally two) long bristles from the upper apical angle down and forward with 1-6 anterior finer bristles. Clasper (Fig. 36): basimere slightly elongated with a rounded apex, the vertical arm of the manubrium with a hump near the junction with the dorsal and horizontal portion and a more or less marked tubercle on this angle. Telomere long and straight, widening in the distal quarter, apex extending beyond the tip of the basimere and markedly rounded on its posterior angle. Setation limited to the upper third of the posterior margin. Sternite IX (Fig. 37): elongated apical dilation of the proximal arm, distal third with an elongated triangular shape. Posterior margin lightly convex with a patch of about 20 fine bristles, 1-2 longer near the caudoapical angle. Phallosome (Fig. 38): anterior margin moderately convex, hookshaped dorsal lobe with broad, rounded ventral lobe. The hook of the apex is short and often blunted, ventral lobe about twice as long as the width of the hook. Distal part of the hamulus robust, elongated and clubshaped, longitudinal stripes near the posterior margin and the anterior border convex. Endotendons extending beyond the tip of the broad lamina media.

Modified female segments: sternite VII (Fig. 39) a small rounded lobe on the posterior margin reaching the more anterior bristles of the sternite VIII, the posterior margin sinuate or moderately convex above. The lower notch small and rounded. It bears a main row of five long sub-marginal bristles, with 7-12 thiner bristles dorsally. Anal stylet moderately elongated (ratio L/1 2.22.6). Spermatheca (Fig. 40): bulga elongated (ratio $\mathrm{L} / 1=1.8$ ). Hilla lightly shorter than the bulga (ratio $\mathrm{H} / \mathrm{B}=0.85$ ) with a rounded apex and frequently a visible papilla. Ductus bursae S-shaped. Sclerotized perula reniform, about twice as high as wide (ratio: 1.7).

Size: male $2.8-3.3 \mathrm{~mm}$, female $3.3-3.6 \mathrm{~mm}$.

\section{DISCUSSION}

T These five new species increase the number of species of Paractenopsyllus cited by Beaucournu \& Fontenille (1993) to 13. It is noteworthy this genus radiated on Madagascar albeit its biotopes are limited to mid-high elevation rainforests. Among these new species the host range seems to be directed either to Microgale insectivores ( $P$. ratovonjatoi, $P$. duplantieri, $P$. juliamarinus) or to Eliurus rodents ( $P$. rouxi, $P$. gemelli). The limited number of specimens do not allow a clear definite host profile but the interaction with the host may be a way of speciation. For several species another hypothesis to be studied is the altitudinal stratification (P. gemelli and P. ratovonjato $i$ ). Two species show remarkable morphological and ecological connections: P. duplantieri and P. juliamarinus. The distribution of these two species are quite distant and may be explained by isolation with relief secondary to climatic events. Endemic Leptopsyllines of Madagascar appear as a very homogenous group. It may be of great interest in speciation process studies to define which mechanisms are involved among host-parasite interactions or bioclimatic factors.

\section{ACKNOWLEDGEMENTS}

F unded by the Ministry of Health of Madagascar (credit IDA-World Bank), the WWF and the Pasteur Institute of Madagascar. Authorization for field studies was provided by the ANGAP and "Direction des Eaux et Forêts de Madagascar". We thank Dr Suzanne Chanteau, manager of the plague program of the IPM, Jean-Felix Roux and Philippe Mauclère, successive directors of the Pasteur Institute of Madagascar for encouraging field and taxonomic works on fleas. We thank Jacques Brunhes (IRD, Montpellier, France), Barry O'Connor (Museum of Zoology, University of Michigan, Ann Arbor, USA) and Jean-Claude Beaucournu (Faculté de Médecine, Rennes, France) for helpful discussions and providing several specimens. Special thanks to Harald Schütz, Vohangy Soarimalala (Université d'Antananarivo, Madagascar), Lala Andria- 
naivolambo (IPM) for collecting mammals and to all the technical staff of the Entomology Laboratory of the Pasteur Institute of Madagascar.

\section{REFERENCES}

Beaucournu J.-C. \& Fontenille D. Contribution à un catalogue des puces de Madagascar. Archives de l'Institut Pasteur de Madagascar, 1993, (édition spéciale), 1-48.

Hopkins G.H.E. \& RoTHSCHILD M. An illustrated catalogue of the Rothschild collection of fleas (Siphonaptera) in the British Museum (Natural History). Vol. V: Leptopsyllidae and Ancistropsyllidae. British Museum, 1971, 530 pp., 30 pl.

KLEIN J.-M. Nouvelles espèces de Paractenopsyllus Wagner, 1938, puces de Madagascar : P. grandidieri n. sp., P. petiti n. sp. et P. viettei n. sp. [Siphonaptera]. Bulletin de la Société entomologique de France, 1965a, 70, 95-104.

KLEIN J.-M. Paractenopsyllus vauceli n. sp., une nouvelle puce de la forêt orientale malgache [Siphonaptera]. Bulletin de la Société entomologique de France, 1965b, 70, 157160.

KLeIn J.-M. Nouvelles puces de Madagascar, Paractenopsyllus randrianasolo $i$ n. sp., P. albignaci n. sp. et Dinopsyllus tsaratananae n. sp. Bulletin de la Société entomologique de France, 1967, 72, 300-310.

Klein J.-M. \& GRENIER P. Redescription de Paractenopsyllus kerguisteli Wagner, 1938 et P. pauliani Lumaret, 1962. Bulletin de la Société entomologique de France, 1965, 70, $287-$ 295.

Klein J.-M. \& Grenier P. Description complémentaire de Paractenopsyllus kerguisteli Wagner, 1938 et clé illustrée de détermination des espèces du genre Paractenopsyllus Wagner (Siphonaptera). Cahiers de l'ORSTOM, sér. Ent. Méd. Parasitol., 1969, 7 (4), 329-339.

Lumaret R. Faune de Madagascar. Vol. XV : Insectes Siphonaptères. Institut de Recherche Scientifique, Tananarive, 1962, 107 pp.

Wagner J. Sur un Cténopsyllide nouveau de Madagascar, Paractenopsyllus kerguisteli $\mathrm{n}$. gen. n sp. Bulletin de la Société de Pathologie Exotique, 1938, 31 (3), 224-228.

Reçu le 16 mai 2003

Accepté le 2 septembre 2003 